\title{
The metabolism of neuropeptides
}

\section{Both phosphoramidon-sensitive and Captopril-sensitive metallopeptidases are present in the electric organ of Torpedo marmorata}

\author{
Anthony J. TURNER* $\ddagger$ and Michael J. DOWDALL $\dagger$ \\ *M.R.C. Membrane Peptidase Research Group, Department of Biochemistry, University of Leeds, Leeds \\ LS2 9JT, U.K., and †Department of Biochemistry, The Medical School, Queen's Medical Centre, Nottingham \\ NG7 2UH, U.K.
}

(Received 10 April 1984/Accepted 4 June 1984)

\begin{abstract}
A membrane fraction from the electric organ of Torpedo marmorata hydrolyses the $\mathrm{Gly}^{3}-\mathrm{Phe}^{4}$ bond of [D-Ala $\left.{ }^{2}, \mathrm{Leu}^{5}\right]$ enkephalin as well as the Gly-His bond of benzoylGly-His-Leu. The hydrolysis of benzoyl-Gly-His-Leu is completely inhibitable by Captopril $\left(\mathrm{I}_{50}=19 \mathrm{nM}\right)$, consistent with peptidyl dipeptidase activity, but enkephalin hydrolysis is inhibited to a maximum of only $70 \%$. The residual activity hydrolysing enkephalin is inhibited by phosphoramidon $\left(\mathrm{I}_{50}=15 \mathrm{nM}\right)$ and therefore resembles endopeptidase-24.11, a mammalian plasma-membrane enzyme implicated in the metabolism of neuropeptides. Both enkephalin-hydrolysing activities in Torpedo electric organ are inhibited by 1,10-phenanthroline, like their mammalian counterparts. The peptidases may function in the hydrolysis of endogenous peptides or in neurotransmitter exocytosis in the electric organ.
\end{abstract}

Endopeptidase-24.11 (EC 3.4.24.11) and peptidyl dipeptidase (angiotensin-converting enzyme, EC 3.4.15.1) are two well-characterized mammalian plasma-membrane metalloenzymes involved in the metabolism of biologically active peptides (Matsas et al., 1983; Relton et al., 1983; Saffer, 1976; Erdös et al., 1978). Both enzymes can hydrolyse the $\mathrm{Gly}^{3}-\mathrm{Phe}^{4}$ bond of enkephalin, are present in synaptic membranes and have been implicated in the physiological inactivation of this opioid peptide (Schwartz, 1983; Benuck \& Marks, 1979). The two enzymes can be distinguished by, among other criteria, their differential sensitivity to inhibitors. Endopeptidase-24.11 is competitively inhibited by phosphoramidon $\left(\mathrm{I}_{50}=8 \mathrm{nM}\right.$; Fulcher \& Kenny, 1983), whereas peptidyl dipeptidase is uniquely sensitive to Captopril $\left(\mathrm{I}_{50}=23 \mathrm{nM}\right.$; Cushman et al., 1977). Opiates have been shown to modify cholinergic transmission (Bixby \& Spitzer, 1983), and an enzyme resembling mammalian peptidyl dipeptidase has been identified in Torpedo californica on the basis of its sensitivity to Captopril (Altstein et al., 1984). In the present paper, we demonstrate that a mem-

Abbreviations used: Bz, benzoyl; h.p.l.c., highpressure liquid chromatography.

$\ddagger$ To whom correspondence should be addressed. brane preparation from the electric organ of Torpedo marmorata hydrolyses the $\mathrm{Gly}^{3}-\mathrm{Phe}^{4}$ bond of $\left[\mathrm{D}-\mathrm{Ala}^{2}, \mathrm{Leu}^{5}\right]$ enkephalin and that this is attributable to two separate enzyme activities. One of these activities also hydrolyses the artificial substrate Bz-Gly-His-Leu and is inhibited by Captopril, and therefore bears a close similarity to mammalian peptidyl dipeptidase. The other activity, comprising approx. $30 \%$ of the total, has characteristics similar to those of endopeptidase24.11 , an enzyme previously identified only in mammalian tissues and particularly enriched in kidney microvilli (for review see Kenny \& Maroux, 1982). The role of the phosphoramidon-sensitive metallopeptidase in the electric organ may be in the metabolism of endogenous peptides or in neurotransmitter exocytosis (Baxter et al., 1983).

\section{Experimental}

\section{Materials}

[D-Ala ${ }^{2}$, Leu $\left.^{5}\right]$ Enkephalin was supplied by Cambridge Research Biochemicals (Harston, Cambridge, U.K.). Bz-Gly-His-Leu and Bz-glycine (hippurate) were from Sigma Chemical Co. Captopril (SQ14225; D-3-mercapto-2-methylpropanoylL-proline) was a gift from the Squibb Institute for Medical Research, Princeton, NJ, U.S.A. Other 
materials were from sources previously noted (Fulcher et al., 1982; Matsas et al., 1983).

\section{Preparation of a membrane fraction}

Torpedo electric organ was obtained from specimens of $T$. marmorata supplied by the Station Biologique d'Arcachon, France, and maintained in sea-water aquaria at $12-15^{\circ} \mathrm{C}$ for periods up to 16 weeks. Electric-organ tissue was removed from fish anaesthetized by chilling in ice, homogenized in $5 \mathrm{vol}$. of $10 \mathrm{~mm}-\mathrm{Tris} / \mathrm{HCl}$ buffer, $\mathrm{pH} 7.4$, in a Braun Multiprac homogenizer, and centrifuged at $100000 \mathrm{~g}$ for $45 \mathrm{~min}$. The membrane pellet was washed and re-centrifuged once with $10 \mathrm{~mm}$-Tris/ $\mathrm{HCl}$ buffer, $\mathrm{pH} 7.4$, and then with the same buffer containing $0.5 \mathrm{M}-\mathrm{NaCl}$. After centrifugation, the membrane pellet was resuspended in $10 \mathrm{mM}$-Tris/ $\mathrm{HCl}$ buffer, $\mathrm{pH} 7.4$, at a protein concentration of $5 \mathrm{mg} / \mathrm{ml}$ and stored frozen at $-70^{\circ} \mathrm{C}$ until required. Subcellular fractionation of electric-organ tissue was carried out as described previously (Dowdall et al., 1982).

\section{Assay of $\left[\mathrm{D}-\right.$ Ala $^{2}$, Leu $\left.^{5}\right]$ enkephalin hydrolysis}

[D-Ala ${ }^{2}, \mathrm{Leu}^{5}$ ]Enkephalin $(0.5 \mathrm{mM})$ was incubated at $37^{\circ} \mathrm{C}$ for $1 \mathrm{~h}$ with Torpedo membranes $(50 \mu \mathrm{g})$ in $0.1 \mathrm{M}$-Tris $/ \mathrm{HCl}$ buffer, $\mathrm{pH} 7.4$, containing $0.1 \mathrm{~mm}$-bestatin in a total volume of $100 \mu \mathrm{l}$ as described previously (Matsas et al., 1983). Incubation of subcellular fractions was carried out in an iso-osmotic buffer system consisting of $300 \mathrm{mM}$ $\mathrm{NaCl} / 100 \mathrm{~mm}$-Tris/HCl buffer, $\mathrm{pH}$ 7.4. The reaction was stopped by the addition of $30 \mu \mathrm{l}$ of $30 \%$ (v/v) acetic acid, and the supernatant obtained after centrifugation was analysed by h.p.l.c.

\section{Assay of BzGly-His-Leu hydrolysis}

The hydrolysis of Bz-Gly-His-Leu was also measured by an h.p.l.c. method. Bz-Gly-His-Leu ( $5 \mathrm{mM}$ ) was incubated in $0.1 \mathrm{M}$-Tris/ $\mathrm{HCl}$ buffer, pH 8.3, containing $0.1 \mathrm{~mm}$-bestatin in a total volume of $100 \mu$ l. The reaction was stopped with $30 \mu \mathrm{l}$ of $30 \%(\mathrm{v} / \mathrm{v})$ acetic acid, and the products (hippurate and His-Leu) were resolved and quantified by h.p.l.c.

\section{Peptide separation by h.p.l.c.}

Reaction conditions for hydrolysis of [D$\mathrm{Ala}^{2}, \mathrm{Leu}^{5}$ ]enkephalin or Bz-Gly-His-Leu were established such that less than $15 \%$ of the particular substrate was hydrolysed, and the reaction rates under these conditions were linear with respect to time of incubation and protein concentration. Peptide reaction products were resolved by h.p.l.c. as described previously (Matsas et al., 1983). Quantification was performed by using the Waters 730 Data Module. Retention times were: [D$\mathrm{Ala}^{2}, \mathrm{Leu}^{5}$ ]enkephalin, $16.6 \mathrm{~min}$; Tyr-D-Ala-Gly,
$5.34 \mathrm{~min}$; Phe-Leu, $12.5 \mathrm{~min}$; Bz-Gly-His-Leu, $14.6 \mathrm{~min}$; Bz-Gly, $10.2 \mathrm{~min}$; His-Leu, $3.8 \mathrm{~min}$; bestatin, $15.2 \mathrm{~min}$.

\section{Results and discussion}

\section{Hydrolysis of $\left[\mathrm{D}-\mathrm{Ala}^{2}, \mathrm{Leu}^{5}\right]$ enkephalin by Torpedo membranes}

The specific activity of $\left[\mathrm{D}-\mathrm{Ala}^{2}, \mathrm{Leu}^{5}\right]$ enkephalin hydrolysis $(3.7 \mathrm{nmol} / \mathrm{min}$ per $\mathrm{mg}$ of protein) was comparable with that previously observed in pig caudate synaptic membranes (Matsas et al., 1983). Significant hydrolysis of the enkephalin analogue occurred only at the $\mathrm{Gly}^{3}-\mathrm{Phe}^{4}$ bond, producing the products Tyr-D-Ala-Gly and Phe-Leu (Fig. 1). In the absence of bestatin from the incubation, the dipeptide Phe-Leu was further hydrolysed by an aminopeptidase present in the membrane preparation. Mammalian endopeptidase-24.11 and peptidyl dipeptidases are both $\mathrm{Zn}^{2+}$-containing en-

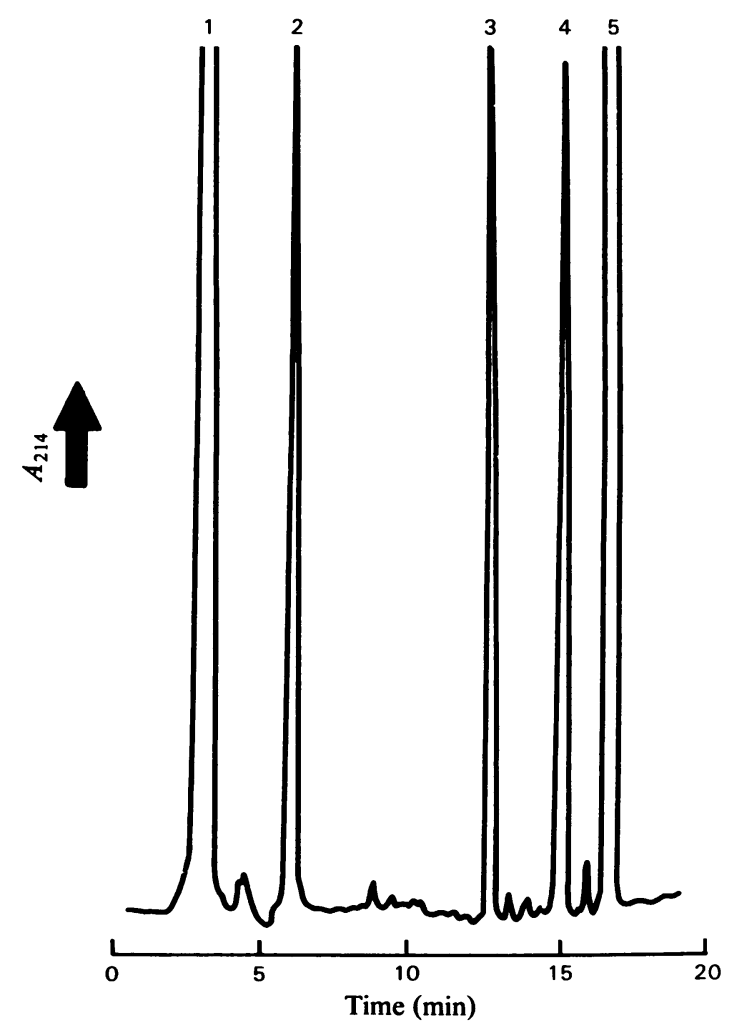

Fig. 1. Hydrolysis of [D-Ala ${ }^{2}$, Leu $\left.^{5}\right]$ enkephalin by Torpedo membranes

The peptide products of $\left[\mathrm{D}-\mathrm{Ala}^{2}, \mathrm{Leu}^{5}\right]$ enkephalin hydrolysis were resolved by h.p.l.c. (see the Experimental section). The resolved peaks correspond to (1) acetic acid, (2) Tyr-D-Ala-Gly, (3) Phe-Leu, (4) bestatin and (5) $\left[\mathrm{D}-\mathrm{Ala}^{2}, \mathrm{Leu}^{5}\right]$ enkephalin. 
zymes, sensitive to chelating agents. More than $95 \%$ inhibition of enkephalin hydrolysis by Torpedo membranes was achieved in the presence of $1 \mathrm{~mm}-1,10$-phenanthroline. Titration of activity with 1,10-phenanthroline indicated the involvement of enzymes with an $I_{50}$ value of approx. $100 \mu \mathrm{M}$ towards this chelating agent (Fig. 2a). When the Torpedo electric organ was subjected to subcellular fractionation (Dowdall et al., 1982), the activity hydrolysing [D-Ala $\left.{ }^{2}, \mathrm{Leu}^{5}\right]$ enkephalin was detectable only in membrane fractions and was enriched 4.1-fold in the synaptosomal preparation relative to the original homogenate. Treatment with $0.1 \%$ Triton $\mathrm{X}-100$ demonstrated that less than $12 \%$ of the synaptosomal peptidase activity was present in an occluded form.

\section{Hydrolysis of Bz-Gly-His-Leu by Torpedo membranes}

Although mammalian peptidyl dipeptidase hydrolyses the $\mathrm{Gly}^{3}-\mathrm{Phe}^{4}$ bond of enkephalin (Benuck \& Marks, 1979), the classical substrate for assay of this enzyme is Bz-Gly-His-Leu (Saffer, 1976). The Torpedo membranes efficiently hydrolysed this substrate, releasing the dipeptide HisLeu, and the activity was completely inhibitable by Captopril (Fig. 2b) with an $I_{50}$ value of approx. 19 nm.

\section{Inhibition of $\left[\mathrm{D}-\right.$ Ala $^{2}$, Leu $\left.^{5}\right]$ enkephalin hydrolysis}

When hydrolysis of $\left[\mathrm{D}-\mathrm{Ala}^{2}, \mathrm{Leu}^{5}\right]$ enkephalin by Torpedo membranes was examined, a maximum inhibition of only $70 \%$ was achieved with Captopril (Fig. 2c), although a similar concentration caused half-maximal inhibition. These observations suggested that the Torpedo membranes contained at least two metallopeptidases. The principal activity, which hydrolysed both [D$\mathrm{Ala}^{2}, \mathrm{Leu}^{5}$ ]enkephalin and Bz-Gly-His-Leu, was sensitive to Captopril and therefore resembled mammalian peptidyl dipeptidase.

The possibility that the second activity, which hydrolysed [D-Ala $\left.{ }^{2}, \mathrm{Leu}^{5}\right]$ enkephalin but not Bz-Gly-His-Leu, may resemble mammalian endopeptidase-24.11 was explored by using the inhibitor phosphoramidon (Kenny, 1977; Matsas et al., 1983; Relton et al., 1983). A combination of Captopril $(1 \mu \mathrm{M})$ and phosphoramidon $(1 \mu \mathrm{M})$ completely inhibited the hydrolysis of [D-Ala $\left.{ }^{2}, \mathrm{Leu}^{5}\right]-$ enkephalin by Torpedo membranes. When inhibition by phosphoramidon alone was examined, a complex titration curve was obtained (Fig. 3a), reflecting the fact that both endopeptidase-24.11 and peptidyl dipeptidase are sensitive to this inhibitor, although with markedly different sensitivities (endopeptidase-24.11, $\mathrm{I}_{50}=8 \mathrm{nM}$; peptidyl dipeptidase, $\mathrm{I}_{50}>100 \mu \mathrm{M}$ for the mammalian kidney enzymes; R. Matsas, A. J. Kenny \& A. J. Turner, unpublished work). Since endopeptidase24.11 is not inhibited by micromolar concentrations of Captopril (Fulcher \& Kenny, 1983; Relton et al., 1983), it proved possible to examine selectively the effect of phosphoramidon under conditions where the peptidyl dipeptidase is
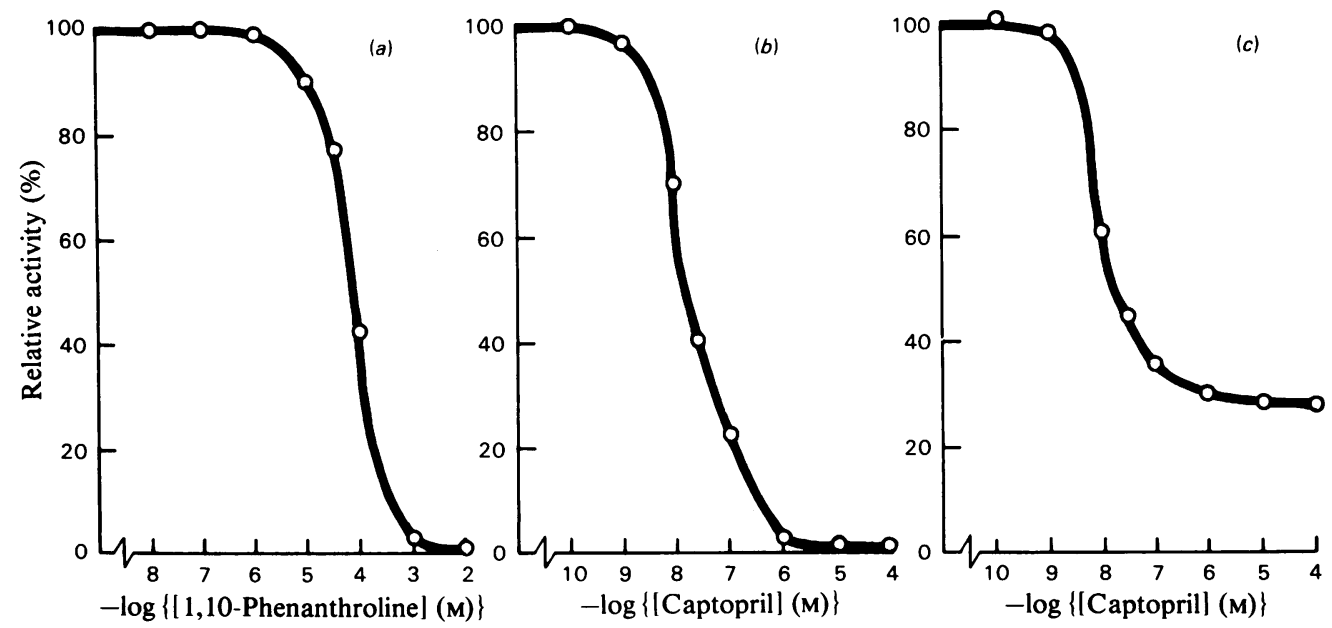

Fig. 2. Effects of 1,10-phenanthroline and Captopril on hydrolysis of [D-Ala ${ }^{2}$,Leu $\left.{ }^{5}\right]$ enkephalin and Bz-Gly-His-Leu by Torpedo membranes

(a) Inhibition of $\left[\mathrm{D}-\mathrm{Ala}^{2}, \mathrm{Leu}^{5}\right]$ enkephalin hydrolysis by 1,10-phenanthroline; (b) inhibition of Bz-Gly-His-Leu hydrolysis by Captopril; $(c)$ inhibition of $\left[\mathrm{D}-\mathrm{Ala}^{2}, \mathrm{Leu}^{5}\right]$ enkephalin hydrolysis by Captopril. In the last case, the maximum inhibition obtained was $71 \%$. The inclusion of $1 \mu \mathrm{M}$-phosphoramidon in addition to Captopril resulted in complete inhibition of $\left[\mathrm{D}-\mathrm{Ala}^{2}, \mathrm{Leu}^{5}\right]$ enkephalin hydrolysis. The hydrolysis of $\mathrm{Bz}-\mathrm{Gly}-\mathrm{His}-\mathrm{Leu}$ by Torpedo membranes was inhibited by $95 \%$ by $1 \mathrm{~mm}-1,10$-phenanthroline (results not shown). 

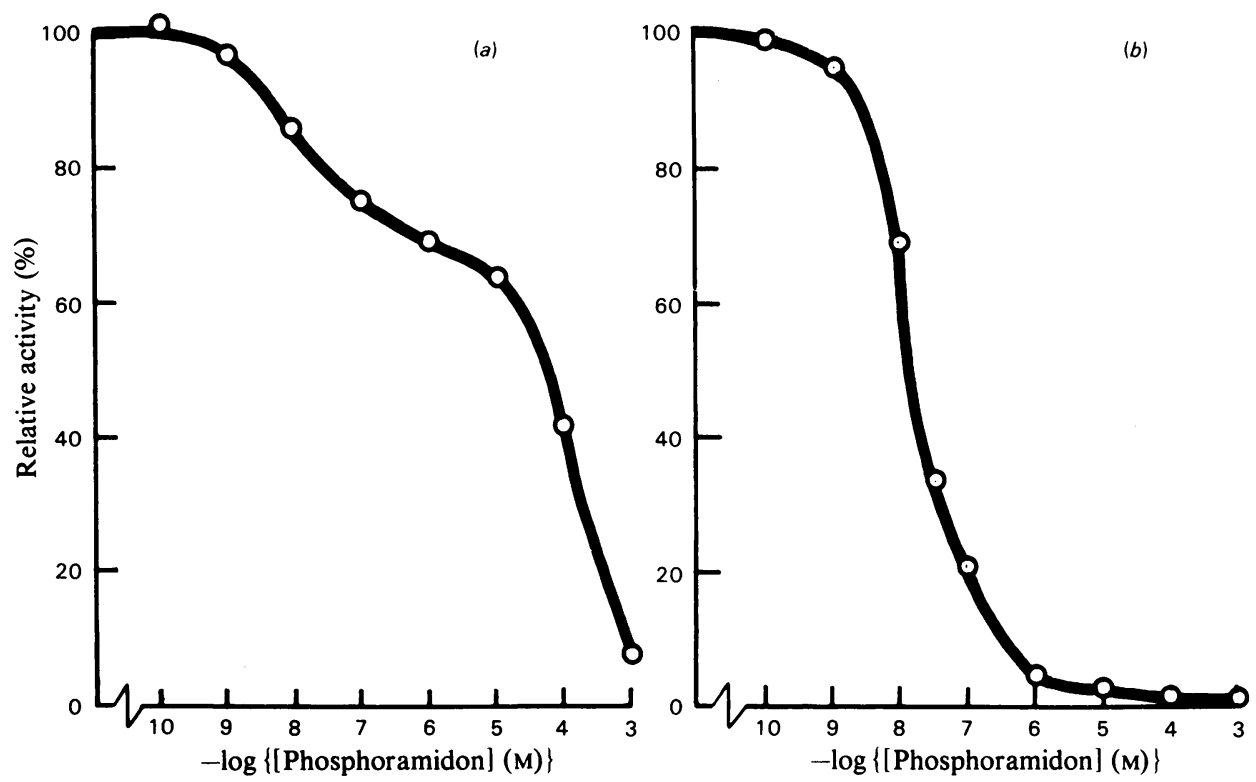

Fig. 3. Effect of phosphoramidon on [D-Ala ${ }^{2}$ Leu $\left.{ }^{5}\right]$ enkephalin hydrolysis in (a) the absence and (b) the presence of $10 \mu \mathrm{M}-$ Captopril

In the latter case, phosphoramidon appears to inhibit a single enzyme activity with an $\mathrm{I}_{50}$ value of approx. $15 \mathrm{nM}$.

completely inhibited (Fig. $3 b$ ). In this case, a sharp titration curve was obtained for phosphoramidon inhibition $\left(\mathrm{I}_{50}=15 \mathrm{nM}\right)$, indicating the additional presence in the Torpedo membranes of an enzyme activity with similar characteristics to mammalian endopeptidase-24.11 (see, e.g., Kenny \& Maroux, 1982). The relative concentrations of the two enzymes differ, though, from those in pig caudate synaptosomes, where the endopeptidase, rather than peptidyl dipeptidase, is the major activity hydrolysing [D-Ala ${ }^{2}, \mathrm{Leu}^{5}$ ]enkephalin (Matsas et al., 1983).

\section{Conclusions}

Membrane preparations from the electric organ of $T$. marmorata contain enkephalin-hydrolysing activities resembling two peptidases previously believed to be of restricted distribution among mammals. Peptidyl dipeptidase occurs in a number of mammalian tissues, but its major location is considered to be lung (Cushman \& Cheung, 1971), where it inactivates bradykinin and also catalyses the hydrolysis of angiotensin I to yield the vasoactive peptide angiotensin II. Since a similar activity has now been detected in a specialized tissue, the electric organ of Torpedo, its role in the metabolism of biologically active peptides clearly needs to be re-assessed. Endopeptidase-24.11 was, until a few years ago, thought to be located exclusively in kidney microvilli, which is reflected in its official enzyme classification as 'kidney brush border neutral proteinase' (Nomenclature Committee of the International Union of Biochemistry, 1979). It is now also known to be located in membrane fractions from various mammalian tissues, including pituitary and brain (Orlowski \& Wilk, 1981; Matsas et al., 1983). This phosphoramidon-sensitive endopeptidase has been implicated in the physiological inactivation of enkephalins and substance P (Schwartz, 1983; Matsas et al., 1983) and, at the mammalian neuromuscular junction, in neurotransmitter exocytosis (Baxter et al., 1983). The functions of the Torpedo endopeptidase, and how closely it resembles its mammalian counterpart, must await its purification and further characterization. Torpedo tissue may prove useful for exploring the physiological functions of both the Captopril-sensitive and phosphoramidon-sensitive metallopeptidases.

Enkephalins and other neuropeptides are widely distributed throughout the animal kingdom (Kilpatrick et al., 1983; Kreiger, 1983), and, in the mammalian nervous system, can co-exist with other neurotransmitters (Osborne, 1983). The possibility that endogenous peptides may modulate acetylcholine action, or be co-loçalized with acetylcholine in the Torpedo electric organ, a tissue thought to be exclusively of cholinergic innervation, deserves consideration. 
We thank the Medical Research Council (A. J. T.) and the Wellcome Trust (M. J. D.) for financial support. We also thank Dr. A. J. Kenny for advice and Mr. J. Hryszko for expert technical assistance.

\section{References}

Altstein, M., Dudai, Y. \& Vogel, Z. (1984) FEBS Lett. 166, 183-188

Baxter, D. A., Johnston, D. \& Strittmatter, W. J. (1983) Proc. Natl. Acad. Sci. U.S.A. 80, 4174-4178

Benuck, M. \& Marks, N. (1979) Biochem. Biophys. Res. Commun. 88, 215-221

Bixby, J. L. \& Sptizer, N. C. (1983) Nature (London) 301, 431-432

Cushman, D. W. \& Cheung, H. S. (1971) Biochim. Biophys. Acta 250, 261-265

Cushman, D. W., Cheung, H. S., Sabo, E. F. \& Ondetti, M. A. (1977) Biochemistry 16, 5484-5491

Dowdall, M. J., Golds, P. R. \& Strange, P. G. (1982) J. Physiol. (Paris) 78, 379-384

Erdös, E. G., Johnson, A. R. \& Boyden, N. J. (1978) Biochem. Pharmacol. 27, 843-848

Fulcher, I. S. \& Kenny, A. J. (1983) Biochem. J. 211, 743753
Fulcher, I. S., Matsas, R., Turner, A. J. \& Kenny, A. J. (1982) Biochem. J. 203, 519-522

Kenny, A. J. (1977) in Proteinases in Mammalian Cells and Tissues (Barrett, A. J., ed.), pp. 393-444, Elsevier, Amsterdam

Kenny, A. J. \& Maroux, S. (1982) Physiol. Rev. 62, 91128

Kilpatrick, D. L., Howells, R. D., Lahm, H.-W. \& Udenfriend, S. (1983) Proc. Natl. Acad. Sci. U.S.A. 80, 5772-5775

Krieger, D. T. (1983) Science 222, 975-985

Matsas, R., Fulcher, I. S., Kenny, A. J. \& Turner, A. J. (1983) Proc. Natl. Acad. Sci. U.S.A. 80, 3111-3114

Nomenclature Committee of the International Union of Biochemistry (1979) Enzyme Nomenclature, p. 344, Academic Press, New York, San Francisco and London

Orlowski, M. \& Wilk, S. (1981) Biochemistry 20, 4942 4950

Osborne, N. N. (1983) in Dale's Principle and Communication between Neurones (Osborne, N. N., ed.), pp. 4968, Pergamon Press, Oxford

Relton, J. M., Gee, N. S., Matsas, R., Turner, A. J. \& Kenny, A. J. (1983) Biochem. J. 215, 519-523

Saffer, R. L. (1976) Annu. Rev. Biochem. 45, 73-94

Schwartz, J.-C. (1983) Trends Neurosci. 6, 45-48 